\title{
THE SOCIOCULTURAL SIGNIFICANCE OF COURT INSTITUTIONS IN COLONIAL VIRGINIA
}

\author{
Pavel V. Vostrikov \\ Kursk State University, Kursk, Russian Federation
}

\begin{abstract}
In this article the author examines the sociocultural significance of courts in colonial Virginia. Virginia was agrarian "tobacco" colony, where the settlements of urban type did not get proper development. In this connection, court days were very important occasions for social gatherings, when colonists not only might participate in court hearings, but became involved in various social interactions such as news exchange, business transactions, cockfighting, horse racing and attending taverns. If not found in rare towns court buildings were situated at road junctions and other convenient places to be more easily accessible for inhabitants of the colony. The author also provides a glimpse into the issues of law and order, crime and punishment as well as the general state of the colonial system of justice. During the colonial period the differences between judicial, executive and legislative branches of government were not distinct yet and the institution of the county court had immense importance as it combined all the three types of power on a local level. The court of oyer and terminer dealt with criminal offences. The General court in Williamsburg, the colonial capital, was the main court in Virginia which considered the most crucial cases. The colonial legal system was initially based on English traditions and precedents but it was constantly modified largely due to the singularities of the colony such as abundance of free land and chattel slavery.

Key words: colonial Virginia, court day, peace justices, crime and punishment, law and order, social life.

Citation. Vostrikov P.V. The Sociocultural Significance of Court Institutions in Colonial Virginia. Vestnik Volgogradskogo gosudarstvennogo universiteta. Serija 4, Istorija. Regionovedenie. Mezhdunarodnye otnoshenija [Science Journal of Volgograd State University. History. Area Studies. International Relations], 2017, vol. 22, no. 3, pp. 52-63. (in Russian). DOI: https://doi.org/10.15688/jvolsu4.2017.3.5.
\end{abstract}

УДК 94:34(73)“16/17”

ББК 63.3(7)51
Дата поступления статьи: 26.12.2016

Дата принятия статьи: 25.04.2017

\section{СОЦИОКУЛЬТУРНОЕ ЗНАЧЕНИЕ СУДЕБНЫХ ИНСТАНЦИЙ В КОЛОНИАЛЬНОЙ ВИРГИНИИ}

\author{
Павел Вячеславович Востриков \\ Курский государственный университет, г. Курск, Российская Федерация
}

\begin{abstract}
Аннотация. В данной работе автор исследует социокультурные аспекты судебных инстанций в колониальной Виргинии. Виргиния была аграрной, «табачной» колонией, в которой поселения городского типа не получили развития. Поэтому для жителей Виргинии дни судебных заседаний были очень важными событиями, когда колонисты собирались у здания суда не только для участия в его непосредственной работе. Они б торговали, проводили скачки, петушиные бои и обсуждали последние новости в таверне. Автор также расㄱ. сматривает особенности таких проблем, как закон и порядок, преступление и наказание, и представляет картину общего состояния юстиции в колониальный период.

Ключевые слова: колониальная Виргиния, день суда, мировые судьи, преступление и наказание, закон и порядок, общественная жизнь.

Цитирование. Востриков П. В. Социокультурное значение судебных инстанций в колониальной Виргинии // Вестник Волгоградского государственного университета. Серия 4, История. Регионоведение. Международные отношения. - 2017. - Т. 22, № 3. - C. 52-63. - DOI: https://doi.org/10.15688/jvolsu4.2017.3.5.
\end{abstract}


Вопросы функционирования английской правовой системы, судопроизводства в американских колониях не получили достаточного освещения в отечественной историографии. Можно прямо говорить об отсутствии специальных работ по этой теме. В рамках данной статьи исследуются некоторые особенности развития правовой культуры в колониальный период - это, прежде всего, трансформация собственно английских установлений под влиянием местных особенностей. Но больше внимания уделяется социокультурным аспектам восприятия судебных процессов современниками, для которых день суда был значимым культурным явлением.

Виргиния раннего периода исторического развития США была аграрной, «табачной» колонией, с низким уровнем развития ремесел и городской жизни, что объяснялось особенностями ее экономики, и все предпринятые властью попытки создать городские поселения на протяжении всего предреволюционного периода не увенчались успехом [17, vol. 2, p. 471; vol. 3, p. 51]. Джеймстаун, формально являясь столицей колонии на протяжении первого столетия освоения девственной - как трактовали колонисты - американской территории, только стремился стать городом как таковым, даже по меркам времени и колониальных особенностей. Гордое именование его колониальной столицей не должно вводить в заблуждение - Джеймстаун и в лучшие дни имел всего около десятка строений, а бунт Бэкона и пожары привели к его полному запустению к рубежу XVII-XVIII веков. Обустроенный усилиями губернаторов Ф. Николсона и А. Спотсвуда в начале XVIII столетия, Уильямсбург был наиболее успешной попыткой городского строительства, но и он отличался известной провинциальностью в сравнении с другими колониальными столицами Бостоном, Филадельфией и Нью-Йорком. В 1790 г. Ричмонд, самый крупный город Виргинии, насчитывал только 3 тысячи 761 жителя, Филадельфия в 1776 г. имела 30 тысяч, а Нью-Йорк - 25 тысяч жителей [33, p. 188]. Важными центрами силы, могущества колонии являлись плантации известных в Виргинии аристократов - Уестовер У. Берда, плантация Ширли, Сабине Халл и многие другие $[18$, p. 34-42]. Но главное значение для повсед- невной общественной и политической жизни колонии имел институт локального суда, то есть суда графства.

Судебные инстанции колониальной Виргинии имели естественную тенденцию к тому, чтобы соответствовать английским традициям, но в силу того, что развитие колонии в XVII в. имело лихорадочный характер, мы можем отметить в качестве примера несоответствия этим традициям один печально известный эпизод местного законотворчества - Кодекс губернатора Томаса Дейла 1612 г. [8], который был призван навести в колонии, находившейся на грани выживания, порядок железной рукой. Вводилось жесткое авторитарное правление, а смертная казнь полагалась за столь незначительные проступки, как кража курицы или нецензурные выражения [34]. Об этом кодексе были наслышаны английские обыватели, и он отпугивал потенциальных поселенцев. Кроме того, все это не могло не вызывать естественного недовольства колонистов и могло бы привести к бунту, но этого не случилось, и «Законы божеские, моральные и военные» были отменены только в 1618 г. [35, p. 35]. Некоторые исследователи считают, что данный кодекс оказал влияние на формирование последующих законов, связанных с ограничением свободы рабов и их наказаниями [14, p. 41-42].

О состоянии системы судебных инстанций в начале XVIII в., которая к этому времени, как и все общественные институты Виргинии, приобрела известную стабильность, нам сообщает в 1705 г. историк и бытописатель Роберт Беверли: «Они [виргинцы] имеют два типа судебных инстанций, которые различаются лишь юрисдикцией, а именно, генеральный суд и суды графств... Генеральный суд возглавляется губернатором и пятью членами совета, которые по закону являются судьями, имеющими компетенцию во всех уголовных, исправительных, церковных и гражданских делах... Заседания этого суда проходят дважды в год начиная с 15 апреля и с 15 октября и длятся одиннадцать дней... Суды графств имеют законодательную силу, и судьи назначаются губернатором по рекомендации совета. Они состоят из восьми джентльменов графства... и именуются мировыми судьями, шериф назначается для исполне- 
ния судебного процесса. Суд проходит раз в месяц и имеет юрисдикцию в пределах графства... Во исполнении всех дел они следуют тем же приемам, что и Генеральный суд» $[2$, p. 206-209].

В Виргинии происходила определенная эволюция законодательного творчества, в которой английские традиции внимательно изучались, но новые законы принимались с учетом местных условий, что в итоге закончилось Виргинскими резолюциями и Декларацией независимости, то есть окончательным разрывом отношений с Англией $[9$, p. 1589 1590]. К местным особенностям относились: наличие рабства и характерные взаимоотношения между расами, особый статус должника, особая роль приходских советов в местном самоуправлении, большое количество свободных земель. Более радикальные изменения законов произошли уже в переходный период от колонии к штату, от монархии к республиканизму [1, p. 208].

В Виргинии колониального периода губернатор, секретарь колонии, члены совета были назначаемы на свои должности самим королем либо его министрами. Эти должности стали столь прибыльными к середине XVIII в., что их могли занимать только англичане, никогда не покидавшие Англии. Но эти чиновники могли выбирать своих представителей, проживавших в Виргинии и являвшихся непосредственными исполнителями монаршей воли. Они имели право, в свою очередь, своих подчиненных определять на должность депутата-секретаря, а он назначал клерков для локальных судов в Виргинии. Таким образом, была создана и поддерживалась система патронажа, на вершине которой стоял король, а клерк суда, замыкавший данную цепочку, был ответственным за повседневную работу властной структуры на местах [16, p. 54]. Столь же важной особенностью правления являлась размытость различий законодательной, исполнительной и судебной властей. Представители правящего слоя могли занимать несколько должностей в разных органах управления. Все три вида власти объединял в себе местный суд $[32$, р. 80]. Суды отдельных графств являлись подлинными колониальными центрами власти и важным элементом принципа репрезентативности в колониальном самоуправле- нии [13, p. 37-42]. Виргинцы принимали участие в практическом познании законов соответственно своему уровню образования и месту в обществе. Суд был органом правительственным, и общество было обязано своим порядком и организацией именно ему.

Здания суда, где проходили тяжбы, выносились приговоры и принимались различные постановления, являлись центрами политической и общественной жизни графств, своим видом они были призваны символизировать авторитет власти и законности. Это здание обычно находилось в отдалении от поселений, но на удобном для путешествующих пересечении дорог [22, p. 214-216]. Начиная с 1740-х гг. это было чаще всего впечатляющее кирпичное здание с высокими сводчатыми дверями и окнами, пришедшее на смену примитивным деревянным строениям периода начала колонизации. Характерным для эпохи является здание суда в графстве Ганновер [18, p. 30].

Местные суды рассматривали локальные тяжбы и мелкие уголовные дела, утверждали завещания, назначали опекунов для сирот, выдавали лицензии тавернам, определяли состав присяжных, готовили для губернатора рекомендации на судей, шерифов, сборщиков налогов и других важных лиц и даже занимались хозяйственной деятельностью изучали вопросы прокладывания новых дорог и строительства мельниц. Тяжбы и различные претензии обсуждались чаще всего в мае. Летом сессии продолжались, несмотря на изнурительную жару. В сентябре споры были по поводу качества урожая табака, в октябре решалась судьба сирот и бедняков, в ноябре регулировались налоги. В декабре разбирались мелкие правонарушения. Раз в четыре года члены приходского совета собирались для обсуждения границ новых приходов [29, p. 32]. Большую часть дел, рассматриваемых в судах, составляли имущественные иски, долговые обязательства, споры о границах поместий.

Определения права в XVIII столетии гласили, что «каждый должен получить то, что ему причитается» [29, p. 41]. Чтобы обеспечить выполнение этого правила, закон определял обязанности и границы требований, которые участники споров должны были соблюдать. Они также должны были знать, что им 
можно было ожидать от последствий юридических действий. Средой обитания большинства виргинцев являлась табачная плантация, а экономические особенности того времени приводили к хроническому пребыванию фермеров в положении должников. Твердой валюты, циркулирующей в колониальном обществе, было немного, долги оплачивались табаком, и все плантаторы и йомены зависели от рынка, погодных условий, урожая, транспортировки табака в Англию, то есть от массы факторов. Так что долги были неизбежны, и фермеры и плантаторы самого разного уровня благосостояния оказывались втянутыми в эту зависимость [3, p. 143-145]. По решениям судов в таком обществе должников оказывалось множество, но чаще всего они не отправлялись в тюрьму, а были вольны оставаться на свободе и только привлекались к суду для дальнейшего рассмотрения их дел. В губернаторстве А. Спотсвуда в Уильямсбурге была построена кирпичная тюрьма, но она так редко использовалась для должников, что после 1722 г. почти все камеры в ней предназначены были для содержания уголовников [4, p. 111; 6, p. 205]. Х. Джонс сообщал: «Здесь, рядом с тюрьмой, находится и открытый суд для должников, когда они бывают отправлены сюда из других тюрем из прочих графств, но заключенных должников здесь весьма мало, кредиторы проявляют к ним снисходительность, а законы столь благоприятны к должникам, что многие полагают их слишком мягкими» $[20$, p. 30]. Сохранилось еще немало свидетельств, подтверждающих, что заключение в тюрьму должников, если и практиковалось, то носило формальный характер и не отличалось той жестокостью, что в Англии того же периода и позже [11, p. 3-5]. Подобное проявление гуманности являлось, скорее, исключением для виргинского законодательства, и было вызвано, очевидно, распространенностью данного явления. К тому же должники, как правило, не были бедными людьми. Они потому и могли избежать заключения, что возможно было изъять что-либо из их собственности в качестве компенсации [1, p. 207].

Закон призван был обеспечивать общественный порядок и гарантировать, что каждый получал должное воздаяние. Землевладельцы, многие из которых принимали учас- тие в судах, относились к таким процедурам очень серьезно. Тяжб было множество, и они отражали дух соперничества в деле защиты границ своих земельных владений от посягательств соседей. Значительное внимание придавалось церемониалу. Сначала подавалась петиция. При открытии слушаний вставал клерк и, обращаясь прежде всего к судьям, а не к остальным присутствующим, зачитывал обвинение или жалобу. После вызывали как минимум двух свидетелей, которые присягали на Библии. Показания свидетелей принимались во внимание сторонами и обвинения, и защиты. Сложность состояла в конфликте субъективных интересов сторон. Участники сессий, как правило, знали друг друга и имели предвзятое отношение к противоположной партии. Такие процедуры с привлечением сторон должников и истцов заставляли фермеров и плантаторов приходить в суд довольно часто, порой раз в месяц, чтобы наблюдать за бесконечным процессом возвращения старых долгов и появления новых [29, p. 41-43]. Законодательство стремилось ограничить возможности свидетелей. Негры, например, могли приносить какие-либо свидетельства в суд, но только против негров, а не против белых.

Мировые судьи (магистраты) числом от восьми до сорока, в зависимости от размеров графства, избирались из числа уважаемых граждан и утверждались губернатором [1, p. 205]. Это была очень почетная, но не оплачиваемая должность [21. p. 43-47]. Мировые судьи не обладали достаточными юридическими знаниями, и поэтому они полагались на консультации клерка, обращались именно к нему в случае затруднений. Граждане, как правило, с большим почтением относились к магистратам, но так как последние не были хорошими юристами, то допускали ошибки, приводившие к конфузам и насмешкам со стороны публики. Лэндон Картер, служивший в окружном суде Ричмонда, даже пригрозил уйти в отставку - его оскорбило, что собрание с большим уважением относилось к клерку-профессионалу, чем к магистратам [22, p. 225]. Но чаще торжественная атмосфера способствовала преодолению этих неудобств. Важность этих событий символизировали джентльмены в париках и мантиях, вершившие 
правосудие именем Его Величества. Приносилось большое количество клятв.

Периодически происходила круговая смена мировых судей округов и других чиновников, то есть суд как организация претерпевал реконституцию, чтобы избежать пристрастного отношения. Судья или офицер ополчения не мог вступать в должность до произнесения клятв в открытом суде. Он обещал честно исполнять свои обязанности и клялся в верности монарху. Законные сделки, документы о передаче права собственности, кадастровые реестры могли быть изложены в письменном виде только после их громогласного оглашения перед собравшимися и одобрения различных партий и групп свидетелей. То было общество с низким уровнем грамотности и широко распространенной устной культурой с опорой на способности к запоминанию. Юридическая система была основана на письменных документах, но их содержимое должно было сначала быть выражено устно.

Любые случаи неуважения к суду или беспорядков влекли за собой немедленное наказание. Почтение к суду и судьям ожидалось от присутствующих и вознаграждалось снисхождением. Это слово означало особый вид вежливости, который представители высших классов должны были оказывать простолюдинам [12, p. 407]. Время от времени чинная атмосфера нарушалась, порой совсем незначительными событиями. Когда некто Аллен Хотон вошел в зал суда графства Уестморленд в шляпе, судьи указали ему на недопустимость такого поведения. Хотон извинился и заплатил небольшой штраф, после чего судьи были удовлетворены. Таким образом, Хотону напомнили о его невысоком статусе, а судьи подтвердили в очередной раз свой авторитет. Иногда подобные мелкие правонарушения совершались в состоянии опьянения. Некто Ричард Паттерсон, заглянув в зал суда, выругался громко и обозвал присутствовавших собаками, после чего ему был назначен штраф в 29 шиллингов, и он был заключен в колодки до самого окончания заседания. После этого Паттерсон оставался под присмотром шерифа до следующего утра, «пока не протрезвеет» [29, p. 39]. Представители джентри и юристы, которые выражали непочтение к решению суда, подвергались более высоким штрафам. Ричард Лоу подвергся штрафу в размере пяти фунтов за то, что назвал шерифа, судей и клерка негодяями. Последние, по его мнению, запросили у него за свои услуги больше, чем позволял их статус. Когда Джон Боллинг, бывший судья, бургес и богатый плантатор из Хенрико, «в очень грубой манере назвал присутствующих щенками и осыпал проклятиями», то был задержан на некоторое время и подвергнут штрафу [29, p. 40].

В повседневной жизни испытывающие изоляцию и одиночество колонисты удовлетворяли свои потребности в общении и любознательности, устраивая импровизированные собрания, приезжая из многочисленных хозяйств по поводу выборов, проведения судебных заседаний, церковных служб или смотрин народного ополчения - местной милиции. Судебные заседания, таким образом, были важны не только в своем политическом и юридическом предназначении. Они являлись одним из способов прервать вынужденную изоляцию, вызванную особенностями табачной экономики.

Рядом со зданием суда находились таверны и лавки. Уильям Берд, совершая поездку к шахтам Александра Спотсвуда, сделал остановку в графстве Каролина и переночевал у одного из клерков суда. Берд с юмором заметил, что «полковник Армистед и полковник Беверли возвели таверны с хорошим выбором вина и других приятных напитков для почтенных членов суда. Кроме того, есть еще другой трактир, где подают ром - это для публики с более вульгарным вкусом. Такой свободный выбор крепких напитков часто вынуждает Фемиду клевать носом, так что она роняет весы из своих рук» [38, p. 373-374]. Дни, в которые проходили судебные заседания, отмечались общим ажиотажем, совершенно непонятным для наших современников. В колонии, где городские поселения были редки, здания судов в окружении таверн и магазинов, собранные вместе на перекрестках дорог, в определенные дни были свидетелями оживления общественной жизни. Сельские жители чувствовали ритм жизни в зависимости от ритмов природы, но и сессии суда также были для них определенными маркерами времени. Как только заканчивалась зима, в марте суды начинали работу после холодов, 
которые часто заставляли отменять заседания в январе и феврале. Во время проведения сессии сотни местных жителей стекались к зданию суда со всех плантаций и поселений. Простой народ прибывал на этот деревенский форум не для непосредственного участия в сессиях, а для развлечений и для того, чтобы узнать последние новости. Территория рядом со зданием суда превращалась в дни сессий в рыночную площадь. Наиболее любопытные стремились все же узнать основные детали заседаний, и те, кто не мог проникнуть внутрь, приникали к окнам. Торговцы разносили горячительные напитки и закуски, вывешивались коммерческие объявления о продаже рабов, лошадей, свиней и земельных аукционах. Подвыпившие мужчины начинали кулачные поединки под одобрительные крики зевак. Организовывались скачки и петушиные бои. Повсюду разгорался азарт и делались ставки. А мальчишки устраивали игру в пятерочку у стены суда, вызывая раздражение тех, кто председательствовал внутри $[22$, p. 214]. Таким образом, в эти дни наблюдался необычный ажиотаж, виргинцы покидали свои насиженные одинокие гнезда и собирались в каком-то одном месте, создавая некоторую иллюзию общности, что при наличии постоянной конкурентной борьбы было удивительно.

В небольшой заметке из «Виргинии Газетт» в июле 1768 г. сообщалось, что в Сассексе прошла гроза и молния ударила в группу деревьев у окружного суда. В результате были не только расщеплены два дерева, но и убиты три свиньи и две лошади, последние принадлежали некоему немцу Эрену Хорну. «Около ста человек присутствовали в таверне и на улице в пределах трех сотен ярдов от места происшествия. Бедняга, потерявший лошадей, тут же получил компенсацию, которая была собрана по инициативе щедрых джентльменов, посещавших заседание суда» [37]. В тот день джентльмены были непосредственными участниками сессий, а Хорн приехал в это место для торговли. Но разные события того дня вызвали у них чувство общности и причастности к некоей драме, в которой они исполняли свои социальные роли. В данном эпизоде джентри имели возможность не только показать свою щедрость, но и подчеркнуть принадлежность к высокому рангу, что подразумевало благосклонное и покровительственное отношение к простому народу [18, p. 90]. Исследователь А. Рубер рассматривает дни суда как проявление особой драматургии в повседневной жизни, где роли были негласно распределены, и историки могут реконструировать эти драмы благодаря сохранившимся протоколам [29, р. 42].

Исследователи Т. Макклески и Дж. Сквайр не вполне соглашались с представителями школы культурной антропологии А. Рубером и Р. Айзеком относительно такой масштабной популярности дней судебных заседаний среди населения Виргинии. Некоторые сомнения возникли у них при чтении дневников торговца Джеймса Гордона и священника Роберта Роуза. Дневник Гордона охватывает пятилетний период, в нем встречается 14 упоминаний о днях судебных заседаний, но нигде нет комментариев по поводу многочисленной толпы. Что касается Роуза, то он отметил большое количество собравшихся в графстве Августа, у здания суда в 1751 г. как некое необычное для себя зрелище [24, p. 92-93]. Графство Августа занимало тогда приграничное положение; не исключено, что Роуз, приехавший издалека, просто не ожидал увидеть там такую толпу. Не отрицая вероятности того, что проявления общности, описанные выше, могли иметь место, Т. Макклески и Дж. Сквайр отметили, что историки, подобные А. Руберу, скорее делают предположение, чем приводят достаточные доказательства неизменно высокой или хотя бы частой посещаемости дней суда, и решили провести свое историко-метрическое исследование на примере нескольких графств, преимущественно приграничной Виргинии. Они пришли к выводу, что различные документальные свидетельства и учет обстоятельств дают им достаточно доказательств, что некоторые дни суда были многолюдны (200-300 человек), а некоторые - нет, но в любом случае они имели большое экономическое значение по обороту совершаемых сделок вне зависимости от размеров толпы [24, p. 94-98].

Крупными преступлениями, совершаемыми черными рабами, с 1710 г. ведали местные уголовные суды - Ойер-энд-терминер. Кабальные слуги и свободные белые по уго- 
ловным делам были судимы в Уильмсбурге $[25$, p. 418]. Судьи собирались в назначенный день и представляли группу "oyer and terminer», что можно интерпретировать как «слушали-постановили» (от старофранцузского: oyer - «Слушайте! Внимание!», этот возглас произносился три раза клерком суда или шерифом и призывал к тишине; terminer - «заканчивать»). Возгласы порой сопровождались ударами посоха о пол [4, p. 58-59]. Суды такого рода были быстрыми, наказания включали стояние у позорного столба, заключение в колодки, порку, клеймение, погружение в воду на специальном стуле, штрафы, смертную казнь через повешение [7].

Сколько-нибудь продолжительных сроков тюремных заключений не предусматривалось. Тюрьмы были местом заключения преступников только до времени суда. Чаще всего провинциальными тюрьмами были ветхие строения из досок, на ремонт которых власти жалели средства, так что нередко случались побеги [22, р. 217].

Если сервента или раба подозревали в краже, например, мяса, ткани или любого другого товара, то судьи без помощи присяжных разбирали дело, оценивая прежде всего стоимость краденного. Если они определяли, что она превышала пять шиллингов, то несчастного приговаривали к повешению прямо напротив здания суда. Если ценность товара была менее пяти шиллингов, то преступнику оказывалось некое снисхождение - ему ставили клеймо на руке, пороли и отпускали. Было обычным делом, когда в момент прижигания руки каленым железом осужденный кричал «Боже, спаси короля!». Клеймо вора на руке (буква «Т») не только было особым знаком для окружающих и позором для его носителя, в мире невысокого уровня грамотности это был «документ», говоривший еще и о том, что его обладатель не мог в случае рецидива пользоваться снисхождением суда и заслуживал только смертной казни $[18$, p. 92]. Беглые сервенты и рабы получали на плечо клеймо «R» [5, p. 126]. Другие виды клеймения включали буквы «А» (прелюбодей), «В» (богохульник), «D» (пьяница), «F» (драчун), «М» (убийца), «R» (хулиган) [23]. Такая процедура замены смертной казни на клеймение имело название «бенефиция священства» [5, p. 126-
127]. Это был старый средневековый обычай, который освобождал представителей церкви от сурового наказания светским судом как людей, умеющих читать. Постепенно он распространился на всех грамотных, способных воспринимать Библию. В Виргинии со временем этим правом могли пользоваться все грамотные люди [5, p. 126-127; 19, p. 416]. Этот обычай практиковался до конца колониального периода. Декламация нескольких стихов из покаянного псалма могла спасти от повешения, и приговор тогда заключался в прижигании каленым железом кончика большого пальца. Бедные и совсем неграмотные имели меньше шансов на такое снисхождение.

Исполнителем наказания (палачом) не являлся шериф. Эти обязанности были делом депутатов, тюремщиков, заместителей шерифа, даже клерков, которые выполняли опасную и неприятную работу по поддержанию порядка. Иногда судьи принуждали одного преступника наказывать другого. Известен случай, когда один преступник повесил другого, в другом случае экзекуция заключалась в отрезании ушей у позорного столба, что тоже один из преступников сделал с другим.

Во многих случаях суровость или относительная мягкость наказания определялась социальным статусом. Законы трактовались не в пользу негров и белых батраков, а также женщин. За мелкое правонарушение женщине полагалась порка, тогда как белый мужчина отделывался штрафом. За одинаковые серьезные преступления грамотные и неграмотные правонарушители могли понести разные наказания [12, p. 399-400]. Некоторые преступники из числа джентльменов получали в качестве наказания клеймение «холодным железом», что не оставляло никакого следа и не воспринималось как ущемление их чести. Смертная казнь была не такой уж редкой в Виргинии. Данные сорока семи судебных сессий с 1737 по 1772 г. свидетельствуют о 164 случаях осужденных за различные уголовные преступления, из которых было казнено 125 человек [12, p. 404].

Казнь через повешение была наиболее распространена. Виселица могла быть воздвигнута на месте преступления: осужденный прибывал на место казни на телеге, на него набрасывали петлю, и повозка затем продол- 
жала движение. Свидетели таких мрачных сцен порой старались скорей снять тело с виселицы, дабы ускорить конец чудовищного зрелища. Трупы висельников могли быть выданы врачам для исследований или их оставляли на месте казни для устрашения. Имущество казненного, какое имелось, конфисковалось в пользу короны. Кабальные слуги и особенно черные рабы чаще других были приговариваемы к высшей мере наказания. В период с 1704 по 1784 г. 555 рабов были казнены в Виргинии [30, p. 67].

Хотя в Виргинии не было каких-либо значительных выступлений рабов за весь колониальный период, власти их постоянно опасались [39, p. 34]. Количество рабов постоянно росло, вместе с ним усиливались и страхи рабовладельцев, которые принимали жестокие законопроекты, направленные на ограничение свободы негров, и увеличивали суровость наказания [31]. Что касается представителей джентри, то о более редких случаях, когда они подвергались смертной казни, сохранились более детальные свидетельства [16, р. 59].

Важной чертой в деятельности суда в колониальный период было собрание присяжных графства, проходившее дважды - в мае и ноябре. От пятнадцати до двадцати пяти серьезных и достаточно состоятельных фригольдеров могли занять эти почетные места. По закону те, кто обладал собственностью в пятьдесят фунтов стерлингов, могли стать присяжными [17, vol. 6, р. 523]. Хотя судьимагистраты и возглавляли процесс, присяжные также обладали достаточно важными полномочиями. У присяжных, тем не менее, не было возможности стать судьями-магистратами. Лояльные и исполнительные, они раз за разом появлялись в суде, выполняя свои рутинные обязательства, что было дополнением к их другими мелким административным делам. Один из присяжных в такие дни исполнял роль судебного клерка и зачитывал обвинение, которое состояло не только в простой констатации правонарушения, но и в напоминании моральных принципов, на которых строилось благосостояние всего общества. Такие выступления походили более на проповеди, в которых обсуждались последствия нарушения воскресного дня, богохульства, пренебрежения строительством заборов и дорог, драк, пьянства и прочих непотребств. Здесь не только выносилось формальное обвинение, но и делались попытки публично пристыдить нарушителей порядка. Затем все они удалялись в специальную комнату для обсуждения дела. Присяжные исполняли важную функцию посредничества между властью и сообществом. Попытки вызвать чувство стыда могли иметь успех, так как нарушители были известны всем собравшимся и соседям [29, р. 43-46]. Такие меры воздействия, сопровождавшиеся штрафами, применялись, конечно, к свободным белым виргинцам. Слуги и рабы в подобных случаях незначительных правонарушений получали наказание на плантациях от своих хозяев [17, vol. 4, p. 126].

Главным судом колонии был, безусловно, Генеральный суд в Уильямсбурге. В дни ассамблей, судебных заседаний и церковных служб Уильямсбург принимал многочисленных гостей, и население его становилось в два раза больше. В такое время это место действительно по праву можно было назвать колониальной столицей. И в наши дни среди самых известных строений в колониальном Уильямсбурге выделяется здание суда, расположенное посреди главной улицы - Глостер-стрит. Это одна из архитектурных доминант города наряду со зданиями Капитолия, Колледжа Уильяма и Мэри, а также губернаторского дворца. Впрочем, это здание суда появилось незадолго до революции - в 1770 г., а до этого суды проводились в Капитолии [27, p. 45-46; 36, p. 24-25]. Двенадцать членов совета и губернатор собирались для слушаний в апреле и октябре. Они рассматривали дела, относящиеся к трактовке английских королевских законов, и ведали уголовными преступлениями. Здесь также проходили и слушания по уголовным делам один раз зимой и один раз летом. Королева Анна добавила позднее еще одну сессию, то был акт благотворительности, дабы заключенные не томились долгое время в ожидании суда. В Уильямсбурге проходили также и военные суды, в которых участие принимали специально назначенные для этого судьи. Адмиралтейский суд, собирался по необходимости. Он рассматривал дела, связанные с пиратством и нелегальной торговлей [3, p. 71-73; 20, p. 28-29]. 


\section{ВСЕОБЩАЯ ИСТОРИЯ}

Все судопроизводство велось согласно английским законам и статутам, принятым еще во времена королевы Елизаветы I. Принимались и новые постановления, связанные с особенностью жизни на плантациях, хотя Генеральная ассамблея не имела полномочий принимать новые законы или отменять старые. Поэтому, те законы, которые казались необходимыми при учете виргинских реалий, предлагались на Ассамблее, обсуждались и отправлялись на рассмотрение в Англию. Если же законопроекты не встречали одобрения монарха, они не принимались или могли быть аннулированы [20, p. 63-64]. Судьи Генерального суда были представлены в верхней палате Ассамблеи, тогда как судьи местных судов занимали места в нижней палате [28, p. 142-143]. Судьи обоих уровней вели также большую административную работу. Судьи Генерального суда в Уильямсбурге имели большие полномочия, иногда они были способны обуздать властные порывы губернатора [4, p. 122-123].

Суды имели важнейшее значение в организации общества. Они являлись гарантами закона, а закон определял права и обязанности. Суды определяли иерархию классов, судьи как землевладельцы представляли патриархальную систему собственности и стремились к соблюдению английских законов для «пользы и нужд подданных при их согласии и одобрении» [18, p. 94]. Несмотря на некоторые недостатки, местные суды были хорошо приспособленными институтами к условиям колониальной Виргинии. Опыт, который мировые судьи приобретали в ходе заседаний и исполнения различных административных обязанностей, был прекрасной юридической школой при отсутствии получения полноценного юридического образования. В дни суда, когда в одном месте могли собираться большие группы народа, менее образованные массы получали возможность не только узнать новости, но получить основы знания в области права от тех, кто был более образован и просвещен. Это была хорошая практическая школа [32, p. 61-62]. Этот опыт был особенно важен в тот исторический момент, когда Виргиния разрывала связи с Британией. Если в середине XVIII столетия представители местной элиты и управленцы метрополии могли отметить устойчивость созданной ими законодательной системы, а виргинцы были лояльными подданными и чтили закон, то со временем выявились и недостатки данной системы взаимоотношений, которые привели к обрушению колониального порядка [26, p. 758-759]. Но к этому времени колония уже имела многочисленный класс, имеющий навыки администрирования и знание законов, что во многом объясняет появление на политической сцене представителей «виргинской династии» с лидирующей ролью Джефферсона, Маршалла и Мэдисона $[15$, р. 485-506]. Одним из результатов их деятельности стало появление в 1779 г. в Колледже Уильяма и Мэри первого в Америке специализированного юридического факультета при активном участии Т. Джефферсона [10, p. 348-350].

Юридическая система, наряду с другими виргинскими институтами, претерпевала постоянные изменения на протяжении колониального периода. Английские традиции и прецеденты не всегда могли быть применены на практике: сказывались особенности быта, социальной структуры. Сопротивление парламентским актам, переросшее впоследствии в стремление к независимости, тем не менее, как раз и было мотивировано знанием английского права и требованием соблюдения законности. Суды играли роль важных информационных центров в колонии с низким уровнем плотности населения и постоянного продвижения границы. Судебные сессии были связаны также с потребностью колонистов к общению и служили для них поводом предаваться различным популярным формам досуга.

\section{СПИСОК ЛИТЕРАТУРЫ}

1. Джефферсон, Т. Автобиография. Заметки о штате Виргиния / Т. Джефферсон. - Л. : Наука, 1990. $-314 \mathrm{c}$.

2. Beverley, R. The History and the Present State of Virginia / R. Beverley. - Richmond : J.W. Randolph, 1855. $-264 \mathrm{p}$.

3. Breen, T. H. Tobacco Culture: The Mentality of the Great Tidewater Planters on the Eve of Revolution / T. H. Breen. - Princeton : Princeton University Press, 2001. $-216 \mathrm{p}$.

4. Chitwood, O. P. Justice in Colonial Virginia / O. P. Chitwood. - Baltimore : John Hopkins Press, 1905. $-125 \mathrm{p}$. 
5. Chumbley, G. L. Colonial Justice in Virginia. The Development of a Judicial System: Typical Laws and Cases of the Period / G. L. Chumbley. - Richmond : Dietz Press, 1938. - 174 p.

6. Coleman, P. J. Debtors and Creditors in America: Insolvency, Imprisonment for Debt and Bankruptcy, 1607-1900 / P. J. Coleman. - Washington : Beard Books, 1999. - 317 p.

7. Cox, A. J. Bilboes, Brands, and Branks: Colonial Crimes and Punishments / A. J. Cox // Colonial Williamsburg Journal. - 2003. - Electronic text data. Mode of access: http:/www.history.org/foundation/ journal/spring03/branks.cfm (date of access: 10.10.2016). - Title from screen.

8. Dale's Code. Lawes Divine, Morall and Marshall (Laws of 1612). - Electronic text data. - Mode of access: http://moglen.law.columbia.edu/ALH/ lawesdivine.pdf (date of access: 12.09.2016). - Title from screen.

9. Davis, R. B. Intellectual Life in the Colonial South. 1585-1763 : in 3 vols. / R. B. Davis. - Knoxville : University of Tennessee Press, 1979. - $1810 \mathrm{p}$.

10. Dworkin, I. B. America's First Law School. The College of William and Mary / I. Dworkin // American Bar Association Journal. - 1951. - Vol. 37, № 5. - P. 348-350.

11. F.H. Imprisonment for Debt in Colonial Virginia // Virginia Magazine of History and Biograph. - 1927. Vol. 35, № 1. - P. 1-6.

12. Fischer, D. H. Albion's Seed: Four British Folkways in America / D. H. Fischer. - N. Y. : Oxford University Press, 1989. - 946 p.

13. Fiske, J. Old Virginia and her Neighbors : in 2 vols. Vol. II / J. Fiske. - Boston ; N. Y. ; Houston : Mifflin and Company, 1897. - $421 \mathrm{p}$.

14. Friedman, L. M. A History of American Law /L. Friedman. - N. Y. : Simon and Schuster, 2010. -787 p.

15. Green, J. P. Foundations of Political Power in the Virginia House of Burgesses, 1720-1776 / J. P. Green // The William and Mary Quarterly, $3^{\text {rd }}$ Ser. - 1959. Vol. 16, № 4. - P. 485-506.

16. Hemphill, J. M. The Wheels of Government and the Machinery of Justice. The Workings of Virginia's Colonial Capitol / J. M. Hemphill, G. S. Terry// Virginia Cavalcade. - 1988. - Autumn. P. 52-65.

17. Hening, W. W. The Statutes at Large, Being the Laws of Virginia : in 13 vols. /W. W. Hening. - Richmond : The Colonial Press, Everett Waddey, Co., 1971.

18. Isaac, R. Transformation of Virginia. 1740-1790 // R. Isaac. - Chapel Hill : University of North Carolina Press, 1982. $-423 \mathrm{p}$.

19. Jefferson, T. Memoirs, Correspondence and Private Letters of Thomas Jefferson : in 12 vols. Vol I / T. Jefferson. - London : Henry Colburn and Richard Bentley, 1829. -464 p.
20. Jones, H. The Present State of Virginia / H. Jones. - N. Y. : Reprinted for Joseph Sabin, 1865. $151 \mathrm{p}$.

21. Justices of Peace in Colonial Virginia, 17571775. - Richmond : Sup. Public Printing, 1922. - 149 p.

22. Lounsbury, C. The Structure of Justice: The Courthouses of Colonial Virginia / C. Lounsbury // Perspectives in Vernacular Architecture, III. - 1989. P. 214-226.

23. Lynch, J. Cruel and Unusual. Prisons and Prison Reform / J. Lynch // Colonial Williamsburg Journal. - 2011. - Electronic text data. - Mode of access: https://www.history.org/Foundation/journal/ Summer11/prison.cfm (date of access: 09.10.2016). Title from screen.

24. McCleskey, T. Court-Day Crowds in Colonial Virginia / T. McCleskey, J. C. Squire // Historical Methods. - 2016. - Vol. 49, № 2. - P. 92-100.

25. Morton, R. L. Colonial Virginia. 1607-1763. : in 2 vols. / R. L. Morton. - Chapel Hill, N.C. : University of North Carolina Press, 1960. - 883 p.

26. Nelson, W. E. Law and the Structure of Power in Colonial Virginia / W. E. Nelson //Valpariso University Law Review. - 2014. - Vol. 48, №3. - P. 757-883.

27. Olmert, M. Official Guide to Colonial Williamsburg/M. Olmert. - Williamsburg: The Colonial Williamsburg Foundation, 2007. - $208 \mathrm{p}$.

28. Rankin, H. F. The General Court in Colonial Virginia: Its Jurisdiction and Personnel / H. F. Rankin // Virginia Magazine of History and Biography. - 1962. Vol. 70, № 2. - P. 142-153.

29. Roeber, A. G. Authority, Law, and Custom: The Rituals of Court Day in Tidewater Virginia, 1720 to 1750 / A. G. Roeber // The William and Mary Quarterly. - 1980. - Vol. 37, № 1. - P. 29-52.

30. Roth, M. P. Crime and Punishment: A History of the Criminal Justice System / M. P. Roth. - Belmont : Wordswoth : Centgage Learning, 2010. - 448 p.

31. Slavery and the Law in Virginia. - Electronic text data. - Mode of access: http://www.history.org/ history/teaching/slavelaw.cfm (date of access: 07.10.2016). - Title from screen.

32. Sydnor, Ch. American Revolutionaries in the Making / Ch. Sydnor // Political Practices in Washington's Virginia.-N. Y. : The Free Press, 1963. -160 p.

33. Talpalar, M. Sociology of Colonial Virginia / M. Talpalar. - N. Y. : Philosophical Library, 1960. $361 \mathrm{p}$.

34. Tarter, B. J. Lawes, Divine, Morall and Martiall / B. J. Tarter// Encyclopedia Virginia. -2012. - Electronic text data. - Mode of access: http://www.encyclopedia virginia.org/Lawes_Divine_Morall_and_Martiall (date of access: 16.08.2016). - Title from screen.

35. The American Journey: A History of the United States / combined by D. Goldfield. - Upper Saddle River : Prentice Hall, 2003. -847 p. 
36. Tyler, L. G. Williamsburg, the Old Colonial Capital / L. G. Tyler. - Richmond, VA : Whittett \& Sherperson, 1907. -284 p.

37. Virginia Gazette. - 1768. - Aug. 4.

38. Wright, L. B. The Prose Works of William Byrd of Westover, Narratives of a Colonial Virginian / L. B. Wright. - Cambridge : Belkamp Press of Harvard University Press, 1966. -438 p.

39. Zinn, H. A People's History of the United States / H. Zinn. - N. Y. : Harper Perennial, 2005. -729 p.

\section{REFERENCES}

1. Jefferson Th. Avtobiografia. Zametki o shtate Virginia [Autobiography. Notes on Virginia State]. Leningrad, Nauka Publ., 1990. 314 p.

2. Beverley R. The History and the Present State of Virginia. Richmond, J.W. Randolph, 1855. 264 p.

3. Breen T.H. Tobacco Culture: The Mentality of the Great Tidewater Planters on the Eve of Revolution. Princeton, Princeton University Press, 2001.216p.

4. Chitwood O.P. Justice in Colonial Virginia. Baltimore, John Hopkins Press, 1905. 125 p.

5. Chumbley G. L. Colonial Justice in Virginia. The Development of a Judicial System: Typical Laws and Cases of the Period. Richmond, Dietz Press, 1938. 174 p.

6. Coleman P.J. Debtors and Creditors in America: Insolvency, Imprisonment for Debt and Bankruptcy, 1607-1900. Washington, Beard Books, $1999.317 \mathrm{p}$.

7. Cox A.J. Bilboes, Brands, and Branks: Colonial Crimes and Punishments. Colonial Williamsburg Journal, 2003. URL: http://www.history.org/ foundation/journal/spring03/branks.cfm (accessed October 10, 2016).

8. Dale's Code. Lawes Divine, Morall and Marshall (Laws of 1612). URL: http://moglen. law.columbia.edu/ALH/lawesdivine.pdf (accessed September 12, 2016).

9. Davis R.B. Intellectual Life in the Colonial South. 1585-1763: in 3 vols. Knoxville, University of Tennessee Press, 1979. 1810 p.

10. Dworkin I.B. America's First Law School. The College of William and Mary. American Bar Association Journal, 1951, vol. 37, no. 5, pp. 348-350.

11. F.H. Imprisonment for Debt in Colonial Virginia. Virginia Magazine of History and Biography, 1927, vol. 35, no. 1, pp. 1-6.

12. Fischer D.H. Albion's Seed: Four British Folkways in America. New York, Oxford University Press, 1989. $946 \mathrm{p}$.

13. Fiske J. Old Virginia and her Neighbors: in 2 vols. Vol. II. Boston and New York, Houston, Mifflin and Company, 1897. $421 \mathrm{p}$.
14. Friedman L. M. A History of American Law. New York, Simon and Schuster, 2010. 787 p.

15. Green J.P. Foundations of Political Power in the Virginia House of Burgesses, 1720-1776. The William and Mary Quarterly, 1959, vol. 16, no. 4, pp. 485-506.

16. Hemphill J.M., Terry G.S. The Wheels of Government and the Machinery of Justice. The Workings of Virginia's Colonial Capitol. Virginia Cavalcade, 1988, pp. 52-65.

17. Hening W.W. The Statutes at Large, Being the Laws of Virginia: in 13 vols. Richmond, The Colonial Press, Everett Waddey, Co., 1971.

18. Isaac R. Transformation of Virginia. 17401790. Chapel Hill, University of North Carolina Press, $1982.423 \mathrm{p}$.

19. Jefferson T. Memoirs, Correspondence and Private Letters of Thomas Jefferson: in $12 \mathrm{vol}$. Vol I. London, Henry Colburn and Richard Bentley, 1829. $464 \mathrm{p}$.

20. Jones H. The Present State of Virginia. New York, $1865.151 \mathrm{p}$.

21. Justices of Peace in Colonial Virginia, 17571775. Richmond, Sup. Public Printing, 1922. 149 p.

22. Lounsbury C. The Structure of Justice: The Courthouses of Colonial Virginia. Perspectives in Vernacular Architecture, III. Columbia, 1989, pp. 214-226.

23. Lynch J. Cruel and Unusual. Prisons and Prison Reform. Colonial Williamsburg Journal (Summer 2011). URL: https://www.history.org/ Foundation/journal/Summer 11/prison.cfm. (accessed October 9, 2016).

24. McCleskey T., Squire J.C. Court-Day Crowds in Colonial Virginia. Historical Methods, 2016, vol. 49, no. 2, pp. $92-100$.

25. Morton R.L. Colonial Virginia: in 2 vols. 1607-1763. Chapel Hill, N.C.: University of North Carolina Press, 1960.883 p.

26. Nelson W.E. Law and the Structure of Power in Colonial Virginia. Valpariso University Law Review, 2014, vol. 48, no. 3, pp. 757-883.

27. Olmert M. Official Guide to Colonial Williamsburg. Williamsburg, The Colonial Williamsburg Foundation, 2007. 208 p.

28. Rankin H.F. The General Court in Colonial Virginia: Its Jurisdiction and Personnel. Virginia Magazine of History and Biography, 1962, vol. 70, no. 2, pp. 142-153.

29. Roeber A.G. Authority, Law, and Custom: The Rituals of Court Day in Tidewater Virginia, 1720 to 1750. The William and Mary Quarterly, 1980, vol. 37, no. 1, pp. 29-52.

30. Roth M.P. Crime and Punishment: A History of the Criminal Justice System. Belmont; Wordswoth, Centgage Learning, 2010. $448 \mathrm{p}$. 
П.В. Востриков. Социокультурное значение судебных инстанций в колониальной Виргинии

31. Slavery and the Law in Virginia. URL: http:// www.history.org/history/teaching/slavelaw.cfm. (accessed October 7, 2016).

32. Sydnor Ch. American Revolutionaries in the Making. Political Practices in Washington's Virginia. New York, The Free Press, 1963. 160 p.

33. Talpalar M. Sociology of Colonial Virginia. New York, Philosophical Library, 1960. 361 p.

34. Tarter B.J. Lawes, Divine, Morall and Martiall. (January 2012). Encyclopedia of Virginia. URL: http:/ /www.encyclopediavirginia.org/Lawes_Divine Morall_and_Martiall (accessed August 16, 2016).
35. Goldfield D., ed. The American Journey: A History of the United States. Upper Saddle River, Prentice Hall, 2003. 847 p.

36. Tyler L.G. Williamsburg, the Old Colonial Capital. Richmond, VA: Whittett \& Sherperson, 1907.284 p.

37. Virginia Gazette, Aug. 4, 1768.

38. Wright L.B. The Prose Works of William Byrd of Westover, Narratives of a Colonial Virginian. Cambridge, Belkamp Press of Harvard University Press, 1966. $438 \mathrm{p}$.

39. Zinn H. A People's History of the United States. New York, Harper Perennial, 2005. 729 p.

\section{Information About the Author}

Pavel V. Vostrikov, Candidate for a Degree, Department of World History, Kursk State University, Zolotaya St., 8, 305000 Kursk, Russian Federation, sortavala2015@inbox.ru, http://orcid.org/0000-00019043-6622

\section{Информация об авторе}

Павел Вячеславович Востриков, соискатель кафедры всеобщей истории, Курский государственный университет, ул. Золотая, 8, 305000 г. Курск, Российская Федерация, sortavala2015@inbox.ru, http://orcid.org/0000-0001-9043-6622 